\title{
Protease activity of extracellular enzyme produced by $B$. subtilis isolated from soil
}

\author{
Md. Gahangir Alam ${ }^{1}$, Md. Ekhlas Uddin²*, Sezanur Rahman ${ }^{3}$, Tasnim Ahmad ${ }^{5}$, Mohammad \\ Reazul Karim4, Dr Mohammad Shakil Mahmood², Mohammad Shah Alam ${ }^{1}$, Md. \\ Nazmuzzaman $^{5}$, Md Jakir Hossain ${ }^{6}$, Pulak Maitra ${ }^{5}$, Md. Sharifull Islam ${ }^{1}$
}

(Corresponding Author) Dept. of Biochemistry \& Molecular Biology, Gono Bishwabidalay, Savar, Dhaka, Bangladesh

\begin{abstract}
Background: Proteases produced by enzymatic method are more environments friendly than chemical process, and they have tremendous potential in the leather industry and in other several industries. In this study extracellular protease producing nonpathogenic Bacillus subtilis was isolated from soil sample and relationship between sporulation and extracellular protease synthesis in large scale cultivation was studied.The enzyme was further characterized, purified, and tested for potential application.

Result: The molecular weight of the protease was found to be $30 \mathrm{KDa}$. Enzyme activity was checked on the presence of different metal ions and effectors. The enzyme was slightly modulated by $\mathrm{MG}^{++}$ion, and significantly by $\mathrm{Hg}^{++}$ ion, while $\mathrm{Zn}^{++}$ion slightly decrease the proteolytic activity. Sulfahydryl reagents, DTT slightly and $\beta-M E$ significantly inhibit the enzyme. EDTA showed no effect on the enzyme suggesting that the enzyme might not be metallo protease. PMSF, a known serine protease inhibitor was seen to totally inhibit the enzyme which indicates that the enzyme is a serine protease. The optimum enzyme activity was observed after 22 hours of incubation of B. subtilis at $37^{\circ} \mathrm{C}$. Conclusions: Crude enzyme contains 285 units of enzyme which have direct dehairing activity. The enzyme was also seen to be able to remove blood and curry stain from clothes; making it a very promising candidate to be used in a leather and detergent industry. Apart from protease the bacterium was also seen to have lipase and collagenase activity. So, the bacteria are potentially good candidate for industrial application.
\end{abstract}

Keywords - Bacillus subtilis, Microbial Proteases, Extracellular enzyme, Enzymatic dehairing, Detergent activity.

\section{INTRODUCTION}

The global market for industrial enzymes in 2012 and 2013 was nearly $\$ 4.5$ and $\$ 4.8$ billion[1]. A compound annual growth rate (CAGR) of $8.2 \%$ from 2013 to 2018 expect that it'll reach around $\$ 7.1$ billion by 2018[2]. Proteases have a large variety of applications mainly in the detergent at food industries and account for nearly $60 \%$ of the industrial market in the world[3]. They find application in a number of biotechnological processes, food processing, Pharmaceuticals, leather industry, silk, bakery, soy processing, meat tendering and brewery industries[4-7]. However, its application in the production of peptide synthesis in organic media is limited by the presence of organic solvents, but microbial proteases are more environments friendly when compared with the chemical process $[5,8]$. Microbial proteases are extracellular in nature and directly secreted into the fermentation broth, thus simplifying downstream processing of the enzyme as compared to proteases obtained from plants and animals $[9$, 19]. Though, optimization of protease could involve several variables such as temperature, $\mathrm{pH}$ and incubation period. In this regard, the Bacillus species specially (B. subtilis) were exploited for their ability to produce extracellular enzymesin submerged fermentation [10-12].

The aim of the study were to culture dehairing protease producing Bacillus sp. in large scale for production and purification of extracellular protease from it, than evaluating practical application of the enzyme in leather and detergent industry.

\section{MATERIAL AND METHODS}

Sample preparation: Bacterial sample isolate by pure culture followed by stick culture from tannery waste rich soil.Gram staining \& spore staining showed that the organism is gram positive and forms spore during adverse condition in the growth medium. After various tests it was suggested and the features agreed with the description of $B$. subtilis in Bergey's Manual of Systematic Bacteriology [13]. It was also identified as B. subtilis with $99.9 \%$ identity by API $50 \mathrm{CHB}[14,22]$ and was also characterized and identified by using a bioinformatics tool PIB (Probabilistic 
Identification of Bacteria)[15] that suggests the organism was $B$. subtilis $(\mathrm{ID}=0.9760)$. B. subtilis was cultured in nutrient broth and incubated in Psychrotherm IncubatorShaker at $37^{\circ} \mathrm{C}$ for $22-24$ hours until the absorbance of growing culture reached 1.5-1.8. Spore staining was carried out to check the shape and the position of bacterial spores and culture was centrifuged at $5000 \mathrm{rpm}$ for 25 minutes to use supernatant as crude enzyme.

Protease activity analysis: The growth was measured at every two hours interval at $37^{\circ} \mathrm{C}$ by $660 \mathrm{~nm}$ light absorbance and proteolytic activity by Kreger and Lockwood [16]method to Determination of co-relation between bacterial growth and extracellular protease synthesis.

Effect of different metal ions ( $\mathrm{ZnSO} 4, \mathrm{MgSO} 4, \mathrm{CuSO} 4$, $\mathrm{NaCl}, \mathrm{KCl}, \mathrm{HgCl} 2$ ) and inhibitors (EDTA, PMSF, sodium thiosulfate , $\beta$-mercaptoethanol, dithiothreitol ) on Protease Activity was determined at $1 \mathrm{mM}$ to $10 \mathrm{mM}$ concentration range by co-incubation of enzyme solution and each ion and inhibitor for 30 minutes at room temperature and then the residual protease activity was determined.

Azocasien assay [17]was carried out to determine extracellular and intracellular protease activity; for extracellular protease crude enzyme was taken but for intracellular, crude enzyme was washed in saline water and disrupted by ultrasonic treatment than centrifuged at $6,000 \mathrm{~g}$ for 15 minutes before the assay.

To evaluate the detergent activity of the enzyme, crude enzyme was used and compared it with several commercial detergents at room temperature.

Enzymatic dehairing: $5 \mathrm{~mL}$ Crude enzyme was added on detergent washed cow hide $(2 \times 2$ inches) to observe enzymatic dehairing capability of the organism. Sodium azide was used at $1 \%$ so other organism cannot grow on subject and incubated for overnight.

Enzyme Purification: For enzyme purification crude enzyme was re-dissolved in buffer and ammonium sulfate was removed by dialysis. After that centricon (ultrafiltration device) is used for collecting enzyme larger than $30 \mathrm{KDa}$. These enzymes were further purified by DEAE cellulose column ion-exchange chromatography, where 1.0 $\mathrm{M}$ Tris- $\mathrm{HCl}$ used as buffer and 0.1-3.0 $\mathrm{M} \mathrm{NaCl}$ solution as gradient. Enzyme purification was confirmed by SDSPAGE.

\section{RESULTS}

Microscopic observation (figure 1) along with growth profile and enzyme activity shows that spore formation start at 10 hour incubation time; it also shows that synthesis of enzyme increases with the increase of sporulation (figure 2).At $37^{\circ} \mathrm{C}$ temperature we also find higher protease activity for extracellular enzyme $(0.28$ absorbance at $440 \mathrm{~nm})$ than intracellular enzyme ( 0.03 absorbance at $440 \mathrm{~nm})$.

\section{Effect of metal ions and other effectors on the protease activity}

Caseinolytic result (Figure 3) show that phenyl methyl sulfonyl fluoride (PMSF) can completely inhibit protease activity which suggest that extracellular might be a serine protease and $\beta$ - mercaptoethanol considerably inhibit the enzyme activity which suggesting that a HS-group may be present at or near the active site. Thiosulfate, potassium chloride, DTT and $\mathrm{Zn}^{++}$ion also inhibit protease activity but not very significantly.

The result also shows that $\mathrm{Mg}^{++}$ion slightly where $\mathrm{Hg}^{++}$ion significantly increased the proteolytic activity. EDTA and other ion have no effect on the protease activity which suggested that the enzyme might not be metallo protease.

Evaluation of detergent activity of the protease enzyme To evaluate the ability of the enzyme to remove stain (blood, curry) from clothes crude enzyme supernatant was used along with/without commercial detergent powder (Figure 4).

\section{Direct dehairing and Collagenase activity}

The crude enzyme was shown to remove the hair completely. As it was shown in Table.1 that the crude enzyme solution contain 285.0 units of enzyme per $\mathrm{mL}$, 356.25 units of enzyme was required to completely remove hair from per square inch of cow hide.So, this enzyme can be used in leather processing and provides an alternative to decrease the environmental contamination load and for a better future.Collagenase activity Test show cow ligment can completely digests in bacterial culture while cell free supernatant could only digest part of it.The fraction collected from ion exchange chromatography showing protease activity (table in supplement file) was subject to SDS-PAGE. After SDS-PAGE a single band was found. Hence we can assume the enzyme has been purified.

\section{DISCUSSION AND CONCLUSION}

During sporulation the organism produces both extracellular and intracellular proteases. From our study isolated extracellular protease enzyme functions at alkaline $\mathrm{pH}$,high salt concentration and temperatures higher than $37^{\circ} \mathrm{C}$.It can effectively remove the blood strain from fabrics suggesting that it may used to fortify of the detergents. Intracellular protease might be associated with some generalized cellular development or normal cellular activity. It might not be involved in this sporulaion or extracellular activity. This 
prediction comes from the result that during 30 hours of monitoring of intracellular enzyme activity no increase in the enzyme activity could be established. Intracellular enzyme activity is not an artifact of enzyme extraction from the cell. Since intracellular enzymes activity is not inhibited by PMSF, or B-Mercapto ethanol, it may be safely concluded that this enzyme is different from extracellular protease reported in this work.

Green chemistry, also called sustainable chemistry, is a chemical philosophy encouraging the design of the products and processes that reduce or eliminate the use and generation of hazardous substance[18]. Leather industry contributes to one of the major industrial pollution problems facing the country[19-21].The application of enzymes its fits many of the principles of green chemistry. Because the optimum enzyme activity was observed after 22 hours of incubation of our isolated $B$. subtilis at $37^{\circ} \mathrm{C}$ where crude enzyme contain 285.0 units of enzyme which have direct dehairing activity.

\section{Competing interests}

The authors declare that they have no competing interests.

Author details

${ }^{1}$ Dept. of Microbiology, Gono Bishwabidalay, Dhaka, Bangladesh

${ }^{2}$ Dept. of Biochemistry \& Molecular Biology, Gono Bishwabidalay, Dhaka, Bangladesh

${ }^{3}$ Dept. of Biology \& Chemistry, North South University, Bangladesh.

${ }^{4}$ Dept. of Microbiology, Chittagong University, Bangladesh

${ }^{5}$ Dept. of Biotechnology \& Genetic Engineering, Islamic University, Kushtia, Bangladesh

${ }^{6}$ Dept. of Biochemistry \& Microbiology, North South University, Bangladesh

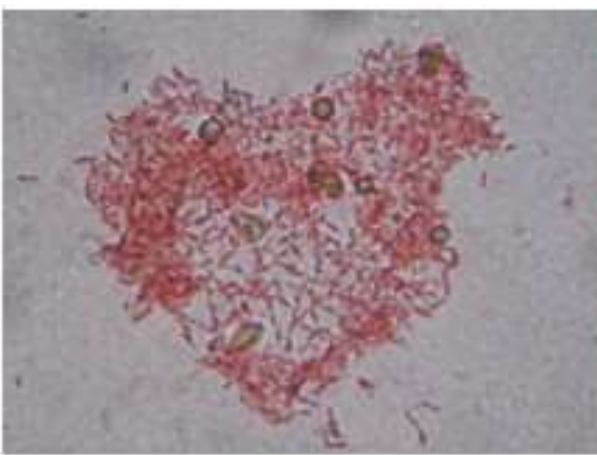

(a) At $10 x$

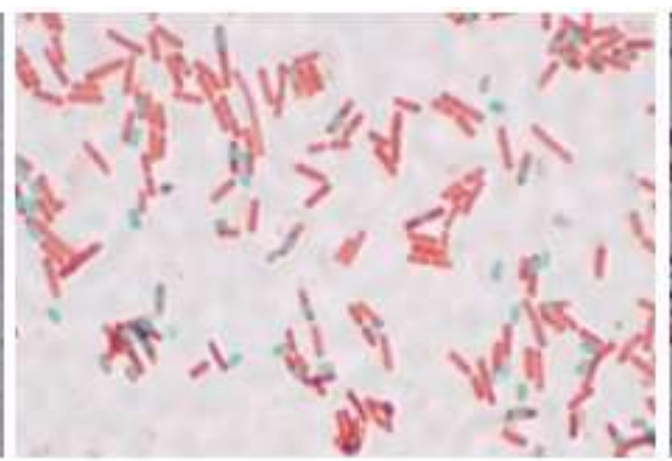

(b) At 100x

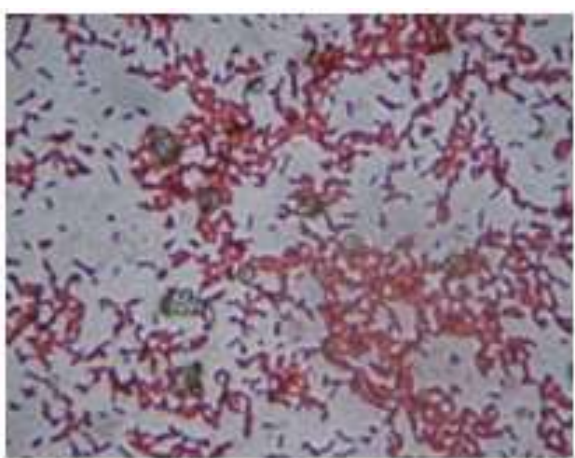

(c) At 50x

Figure 1: Microscopic observation of sporulation at different time intervel (a) at $10^{\text {th }}$ hour (b) at $18^{\text {th }}$ hour (c) at $22^{\text {nd }}$ hour.

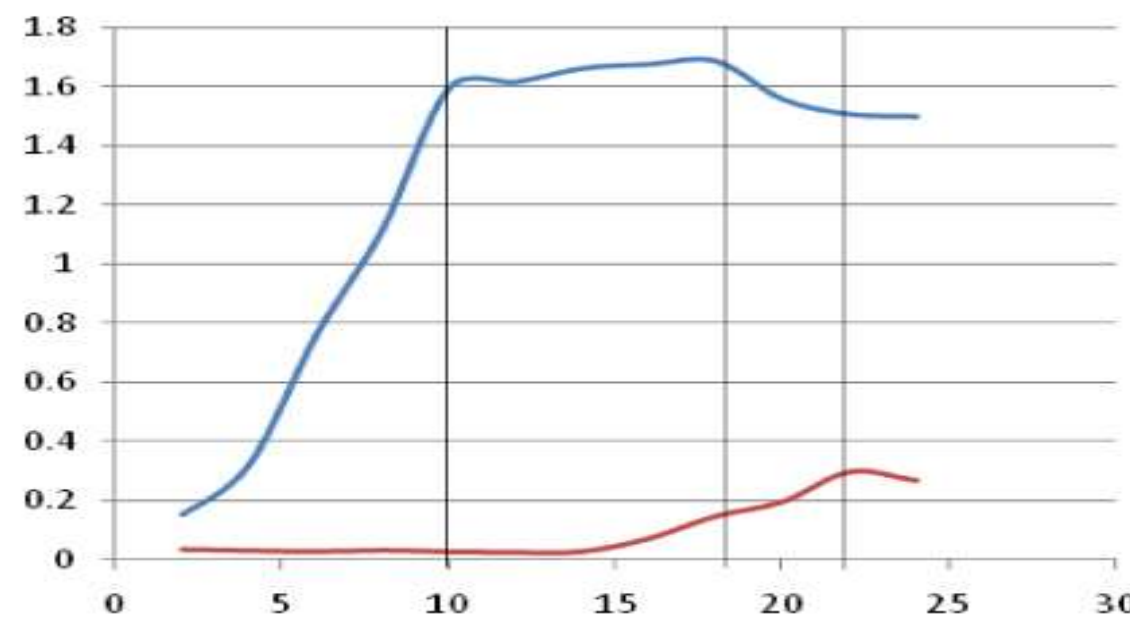

Absorbance at 600nm

- Growth Patern Enzyme Activity

Figure 2: Sporulation start at $10^{\text {th }}$ optimum growth at $18^{\text {th }}$ and highest enzyme activity show at $22^{\text {nd }}$ hour of incubation. 


\section{Caseinolytic activity (\%)}

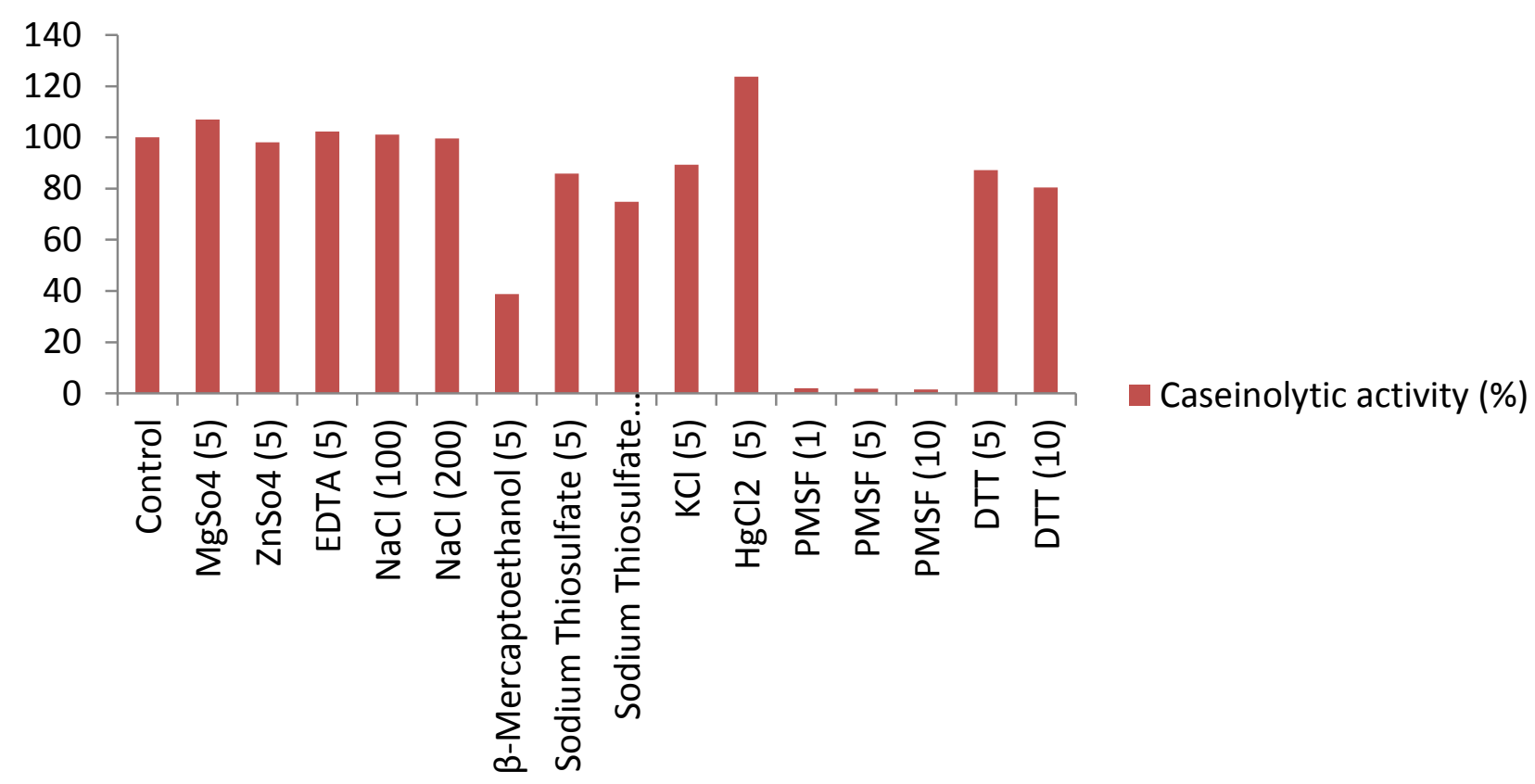

Figure 3: Graphical presentation of the effect of different metal ions and effectors on protease activity.
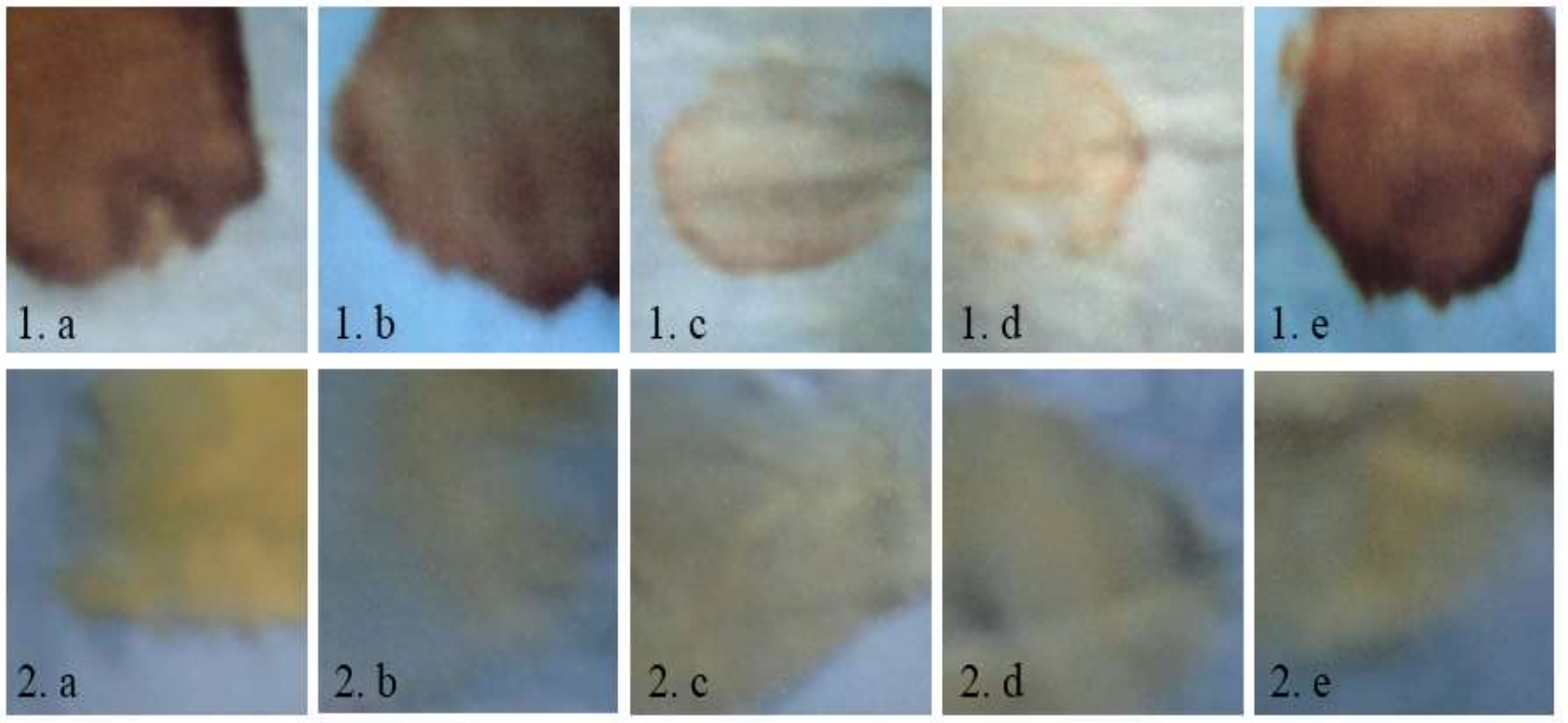

Figure 4: Evaluation of different commercial detergent and the enzyme to remove blood stain from clothe. (1.a) Control, (1.b)

Wheel powder slightly removed the blood stain, (1.c) Wheel powder + enzyme nearly remove all blood stain, (1.d) Enzyme alone is sufficient to remove blood stain, (1.e) Surf Excel could not remove blood stain. And for curry (2.a) Control, (2.b)

Wheel powder, (2.c) Wheel powder + enzyme (2.d) Enzyme alone, (2.e) Surf Excel; all of them were shown to be very negligibly removing curry stain. 
Table.1: Different enzymatic properties of protease at several stage.

\begin{tabular}{|c|c|c|c|c|c|c|}
\hline Stage & 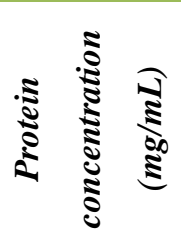 & 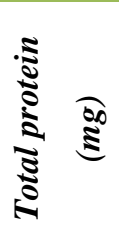 & 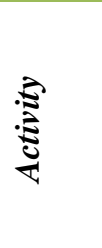 & 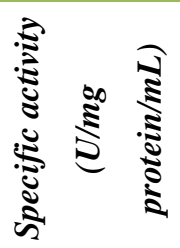 & 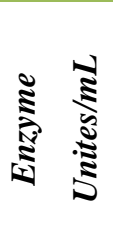 & 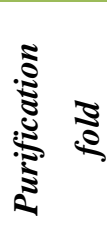 \\
\hline Before purification & 0.75 & 825.0 & 1.25 & 380 & 285 & \\
\hline $75 \%$ saturation with ammonium sulfate & 1.35 & 270.8 & 2.872 & 77.4 & 104.5 & 3.04 \\
\hline After dialysis & 0.49 & 98 & 2.872 & 213.33 & 104.5 & 2.8 \\
\hline After ultra-filtration by centricon & 0.415 & 2.075 & 1.980 & 130.1 & 54.0 & 3.25 \\
\hline
\end{tabular}

Supplementary Table. S.1: Growth profile and protease activity of the organism at $37^{0} \mathrm{C}$.

\begin{tabular}{|c|c|c|}
\hline Time (hours) & Absorbance at $\mathbf{6 0 0} \mathbf{n m}$ (For Growth) & Absorbance at 600 nm (For Protease Activity) \\
\hline 2 & 0.15 & 0.035 \\
\hline 4 & 0.319 & 0.031 \\
\hline 6 & 0.757 & 0.028 \\
\hline 8 & 1.119 & 0.032 \\
\hline 10 & 1.599 & 0.025 \\
\hline 12 & 1.619 & 0.028 \\
\hline 14 & 1.665 & 0.073 \\
\hline 16 & 1.679 & 0.149 \\
\hline 18 & 1.689 & 0.198 \\
\hline 20 & 1.559 & 0.299 \\
\hline 22 & 1.509 & 0.269 \\
\hline 24 & 1.501 & \\
\hline
\end{tabular}


Supplementary Table. S.2: Effect of metal ions and other effectors on the protease activity of the protease.

\begin{tabular}{|c|c|}
\hline Compound (concentration in $m M$ ) & Caseinolytic activity (\%) \\
\hline Control & 100 \\
\hline $\mathrm{MgSO}_{4}(5)$ & 107 \\
\hline $\mathrm{ZnSo}_{4}(5)$ & 98 \\
\hline EDTA (5) & 102.3 \\
\hline $\mathrm{NaCl}(100)$ & 101 \\
\hline $\mathrm{NaCl}(200)$ & 99.5 \\
\hline$\beta$-Mercaptoethanol (5) & 38.8 \\
\hline Sodium Thiosulfate (5) & 85.9 \\
\hline Sodium Thiosulfate (10) & 74.82 \\
\hline $\mathrm{KCl}(5)$ & 89.3 \\
\hline $\mathrm{HgCl}_{2}(5)$ & 123.7 \\
\hline$P M S F(1)$ & 2.04 \\
\hline$P M S F(5)$ & 1.9 \\
\hline PMSF (10) & 1.5 \\
\hline $\operatorname{DTT}(5)$ & 87.2 \\
\hline $\operatorname{DTT}(10)$ & 80.47 \\
\hline
\end{tabular}

Supplementary Table.S.3: Ion exchange chromatography Result (Absorbance at 280 nm).

\begin{tabular}{|c|c|c|c|c|c|c|c|}
\hline \multirow{2}{*}{$\begin{array}{c}\text { Fraction } \\
\text { no. }\end{array}$} & \multicolumn{7}{|c|}{ Eluent Condition } \\
\cline { 2 - 8 } & Tris Buffer & $\mathbf{0 . 1} \mathbf{M ~ N a C l}$ & $\mathbf{0 . 2} \mathbf{M ~ N a C l}$ & $\mathbf{0 . 5} \mathbf{M ~ N a C l}$ & $\mathbf{1 . 0} \mathbf{M ~ N a C l}$ & 2.0 M NaCl & $3.0 \mathrm{M} \mathrm{NaCl}$ \\
\hline 1. & 0.005 & 0.038 & 0.103 & 0.025 & 0.049 & 0.005 & 0.001 \\
\hline 2. & 0.004 & 0.029 & 0.127 & 0.030 & 0.044 & 0.005 & 0.001 \\
\hline 3. & 0.004 & 0.027 & 0.111 & 0.041 & 0.070 & 0.005 & 0.001 \\
\hline 4. & 0.209 & 0.03 .4 & 0.132 & 0.040 & 0.052 & 0.005 & 0.001 \\
\hline 5. & 0.008 & 0.094 & 0.198 & 0.021 & 0.052 & 0.005 & 0.001 \\
\hline 6. & 0.007 & 0.179 & 0.103 & 0.047 & 0.039 & 0.006 & 0.001 \\
\hline 7. & 0.010 & 0.206 & 0.007 & 0.016 & 0.038 & 0.006 & 0.001 \\
\hline 8. & 0.016 & 0.209 & 0.005 & 0.024 & 0.039 & 0.005 & 0.001 \\
\hline 9. & 0.023 & 0.217 & 0.015 & 0.018 & 0.037 & 0.005 & 0.001 \\
\hline 10. & 0.063 & 0.236 & 0.017 & 0.025 & 0.025 & 0.003 & 0.001 \\
\hline
\end{tabular}




\section{REFERENCES}

[1] Singhal P, Nigam V, Vidyarthi A: Studies on production, characterization and applications of microbial alkaline proteases. International Journal of Advanced Biotechnology and Research 2012, 3 (3):653-669.

[2] Dewan S: Global markets for enzymes in industrial applications. BCC Research, BIOO30G 2012.

[3] Anwar A, Saleemuddin M: Alkaline proteases: a review. Bioresource Technology 1998, 64(3):175-183.

[4] Kumar CG, Takagi H: Microbial alkaline proteases: from a bioindustrial viewpoint. Biotechnology advances 1999, 17(7):561-594.

[5] Gupta R, Beg Q, Lorenz P: Bacterial alkaline proteases: molecular approaches and industrial applications. Applied microbiology and biotechnology 2002, 59(1):15-32.

[6] Kamath P, Subrahmanyam V, Rao JV, Raj PV: Optimization of cultural conditions for protease production by a fungal species. Indian journal of pharmaceutical sciences 2010, 72(2):161.

[7] Fujimaki M, Kato H, Arai S, Yamashita M: Application of microbial proteases to soybean and other materials to improve acceptability, especially through the formation of plastein. Journal of Applied Bacteriology 1971, 34(1):119-131.

[8] Ogawa J, Shimizu S: Microbial enzymes: new industrial applications from traditional screening methods. Trends in Biotechnology 1999, 17(1):13-20.

[9] FURHAN J, SHARMA S: INTERNATIONAL JOURNAL OF INVENTIONS IN PHARMACEUTICAL SCIENCES.

[10] Reddy MN, Kumar C, Swathi K, Nagamani B, Venkateshwar S, Rao L: Extracellular alkaline protease production from isolated Bacillus subtilis svr-07 by using submerged fermentation. International journal of pharma Research and development 2011, 3:216-223.

[11]Nigam PS: Microbial enzymes with special characteristics for biotechnological applications. Biomolecules 2013, 3(3):597-611.

[12] Rifaat HM, El-Said OH, Hassanein SM, Selim MS: Protease activity of some mesophilic streptomycetes isolated from Egyptian habitats. Journal of Culture Collections 2007, 5(1):16-24.

[13] Sneath PH, Mair NS, Sharpe ME, Holt JG: Bergey's manual of systematic bacteriology. Volume 2. Bergey's manual of systematic bacteriology Volume 2 1986.
[14] Seldin L, Penido EG: Identification of Bacillus azotofixans using API tests. Antonie van Leeuwenhoek 1986, 52(5):403-409.

[15] Lapage S, BASCOMB S, Willcox W, Curtis M: Identification of bacteria by computer: general aspects and perspectives. Microbiology 1973, 77(2):273-290.

[16] Kreger A, Lockwood D: Detection of extracellular toxin (s) produced by Vibrio vulnificus. Infection and immunity 1981, 33(2):583-590.

[17] Iversen SL, Jørgensen MH: Azocasein assay for alkaline protease in complex fermentation broth. Biotechnology techniques 1995, 9(8):573-576.

[18] Anastas P, Eghbali N: Green chemistry: principles and practice. Chemical Society Reviews 2010, 39(1):301-312.

[19] Md. Ekhlas Uddin, Dr. M. Rahman*, H. M. Faruquee, Md. R. I. Khan, M. Feroz Mortuza, M. H. Rahman \& Pulak Maitra: Isolation, Identification and Partial Characterization of Protease Producing Bacteria that Exhibiting Remarkable Dehairing Capabilities. Global Journals Inc. (USA) 2015, 15(1): 09-18.

[20] Paul H, Antunes APM, Covington AD, Evans P, Phillips PS: Bangladeshi leather industry: an overview of recent sustainable developments. $J$ Soc Leather Technol Chem 2013, 97(1):25-32.

[21] Sharif MI, Mainuddin K: Country case study on environmental requirements for leather and footwear export from Bangladesh. Dhaka: Bangladesh Centre for Advanced Studies 2003.

[22] Strasser J, Kulke E: Temporary resource availability and quality constraints in the global leather value chain-The impact of the festival of sacrifice on the leather industry in Bangladesh. Applied Geography 2013, 45:410-419.

[23] Uddin M. E., Alam M. G., Ahmad T., Mahmud S., Nazmuzzaman M., Alam M. F., Karim M. R., Barman N. C., Arif-uz-Zaman M., Ahammed T. and Faruquee H. M.*: Screening, Optimization and Exploration of Microbial Enzymes with Special Characteristics for Biotechnological Applications. Research J. of Life Sciences, Bioinformatics, Pharmaceutical and Chemical Sciences 2016, 2(3): 178-191. 